\title{
In planta gene expression analysis of Xanthomonas oryzae pathovar oryzae, African strain MAl1
}

\author{
Mauricio Soto-Suárez', Diana Bernal2, Carolina González³, Boris Szurek', Romain Guyot ${ }^{1}$, Joe Tohme² and \\ Valérie Verdier*1
}

\begin{abstract}
Background: Bacterial leaf blight causes significant yield losses in rice crops throughout Asia and Africa. Although both the Asian and African strains of the pathogen, Xanthomonas oryzae pv. oryzae (Xoo), induce similar symptoms, they are nevertheless genetically different, with the African strains being more closely related to the Asian X. oryzae pv. oryzicola (Xoc).

Results: Changes in gene expression of the African Xoo strain MAl1 in the susceptible rice cultivar Nipponbare were profiled, using an SSH Xoo DNA microarray. Microarray hybridization was performed comparing bacteria recovered from plant tissues at 1, 3, and 6 days after inoculation (dai) with bacteria grown in vitro. A total of 710 bacterial genes were found to be differentially expressed, with 407 up-regulated and 303 down-regulated. Expression profiling indicated that less than $20 \%$ of the 710 bacterial transcripts were induced in the first $24 \mathrm{~h}$ after inoculation, whereas $63 \%$ were differentially expressed at 6 dai. The 710 differentially expressed genes were one-end sequenced. 535 sequences were obtained from which 147 non-redundant sequences were identified. Differentially expressed genes were related to metabolism, secretion and transport, pathogen adherence to plant tissues, plant cell-wall degradation, IS elements, and virulence. In addition, various other genes encoding proteins with unknown function or showing no similarity to other proteins were also induced. The Xoo MAl1 non-redundant set of sequences was compared against several $X$. oryzae genomes, revealing a specific group of genes that was present only in MAI1. Numerous IS elements were also found to be differentially expressed. Quantitative real-time PCR confirmed $86 \%$ of the identified profile on a set of 14 genes selected according to the microarray analysis.
\end{abstract}

Conclusions: This is the first report to compare the expression of Xoo genes in planta across different time points during infection. This work shows that as-yet-unidentified and potentially new virulence factors are appearing in an emerging African pathogen. It also confirms that African Xoo strains do differ from their Asian counterparts, even at the transcriptional level.

\section{Background}

Xanthomonas oryzae pv. oryzae (Xoo) is the causal agent of bacterial leaf blight in rice. Bacterial cells on leaf surfaces enters the rice leaf by either swimming passively through the fluid oozing from hydathodes in the morning and spreading systemically in the plant through the xylem, or it enters directly into the xylem through wounds [1]. In Asia, this disease is the most economically important within the irrigated environment. It appeared

\footnotetext{
* Correspondence: Valerie.Verdier@ird.fr

1 UMR 5096 IRD-CNRS-Université de Perpignan, Laboratoire Génome et Développement des Plantes, Institut de Recherche pour le Développement, 911 Avenue Agropolis BP 64501, 34394 Montpellier Cedex 5, France Full list of author information is available at the end of the article
}

in Africa in the 1980s, and has since been growing in importance [2]. The use of varietal resistance is a highly efficient way of controlling the disease in Asia, but, in Africa, adequate control methods and deployment of resistant varieties are still lacking. Among the prerequisites for finding adequate control strategies are an understanding of the biology of the host-pathogen interaction and the characterization of those genes involved in pathogenicity.

Numerous studies [1] have been carried out on the interaction between both host (rice) and pathogen (Asian Xoo strains). In Asia, Xoo shows important variations, as revealed by virulence and DNA fingerprinting analyses [3-5]. A race is a group of strains sharing common pheno- 
type of virulence to a set of host cultivars. In the case of Xoo near isogenic lines (IRBB lines) are being used and more than 30 Xoo races have been reported in Asia so far. New ones are emerging that overcome deployed resistance [6]. Identification of the genes used by the bacteria to colonize plants may give new insights into the plant defence pathways that are vulnerable to pathogen attack and provide better understanding of the processes in both bacterial pathogenesis and plant immunity.

Microarray technology has been widely used to explore transcriptional profiles in plant pathogenic bacteria such as Pseudomonas syringae, Ralstonia solanacearum, Xanthomonas axonopodis, X. campestris, and Xylella fastidiosa [7-15]. These analyses were conducted to study responses to environmental factors such as heat shock, changes in iron bioavailability or carbon sources [7-9], expression changes related to pathogenesis [10-13], and biofilm formation [13]. Another significant field of microarray analysis is that of genome diversity [14] and horizontal gene transfer events [15], using comparative genome hybridization. One example was the recent development of an Xanthomonas oryzae 5K oligoarray, with oligos designed according to the sequences of the genomes of Asian strains of Xoo and X. oryzae pv. oryzicola (Xoc) [16]. Xoc is the causal agent of bacterial leaf streak, a non-vascular counterpart of Xoo [1]. Xoo and $X o c$ showed differentially expressed genes when grown in enriched versus minimal media [16]. For example, the minimal medium XOM2 induces the in vitro expression of the hrp genes in Xoo but not in Xoc, presumably by mimicking the $\mathrm{pH}$ and nutrient content in the apoplast [17]. The great potential of microarray technology was also demonstrated by several other studies that used the technique based on whole or partial plant-bacterial genomes [18-20]. Most analyses addressing bacterial gene expression were conducted under in vitro conditions.

Strain variations were recently documented in wholegenome analyses of three Xoo strains: the Korean Xoo strain KACC10331 [21], the Japanese Xoo strain MAFF311018 [22], and the Philippine Xoo strain PXO99A [23]. A whole-genome sequence is also available for one Asian Xoc strain BLS256. Several characteristics differentiate the Xoo genome from those of other xanthomonads: a higher abundance of IS elements, and prevalence of TAL effector genes of the avrBs3/pthA family $[1,22]$. TAL genes are widespread among Xanthomonas spp., but this family of effectors has expanded specifically in the genomes of Asian X. oryzae pathovars. Recent studies identified African Xoo strains as a significantly different genetic group that appears more closely related to the Asian Xoc than to Asian Xoo [24]. In contrast to Asian Xoo strains, African Xoo strains show a reduced number of both TAL genes and IS elements in their genomes [24]. African Xoo strains induce a non-host hypersensitive response (HR) in tobacco leaves suggesting that these strains display one or several specific non-host HR elicitors, such as type III effectors or harpins. Finally, three new races have been determined among the African strains [24]. However, except for the role of one TAL effector, almost nothing is known about the specific genetic determinants of pathogenicity in Xoo African strains (Yu Y., Szurek B., Mathieu T, Feng X., Verdier V. 2009, unpublished data). Much remains to be learned about the genes involved in the pathogenicity and virulence of this African pathogen. Identification of such genes can improve understanding of how Xoo causes disease.

Efficient methods for recovering bacterial cells directly from plant tissues permit analyses of in vivo expression in plant-pathogen interactions $[25,26]$. Conducting gene expression analyses of bacterial pathogens in planta may improve the understanding of the mechanisms underlying plant-pathogen interactions and may help in the early detection of genes involved in pathogenicity [25,27]. Because whole genome is not yet available for African Xoo strains, we used SSH libraries of Xoo strain MAI1 [28] that were then spotted onto a microarray and used to analyse in planta gene expression at different time points during infection. Combining the SSH method, in vivo analysis, and microarrays to study the Xoo MAI1-rice interaction offers considerable advantages, particularly as in vitro approaches are frequently limited in their ability to mimic all aspects of the in vivo state. Aditionally, constructing an Xoo MAI1 microarray, based on SSH DNA libraries, allows the enrichment of Xoo MAI1 sequences. Hence, the likelihood is higher that the microarray will reveal novel genes involved in Xoo-rice infection. Although the Xoo MAI1 SSH-microarray does not allow analyses of genome-wide gene expression profiles, specific biological questions can be answered more efficiently, for example, identification of virulence determinants in African Xoo strains. In contrast with other large-scale approaches to the study of gene expression in the Xanthomonas genus $[10,16,25,29,30]$, this is the first report to compare bacterial gene expression in planta and at different time points during infection.

\section{Results and discussion}

\section{Bacterial recovery from plant tissues, and RNA isolation}

We determined Xoo MAI1 multiplication in planta at seven time points after infection into five $2-\mathrm{cm}$ leaf sections (A-E, Figure 1). The Xoo strain MAI1 multiplied to a population size of almost $10^{-4}$ colony-forming units (cfu) in section A within $12 \mathrm{~h}$ after inoculation (hai). Thereafter, the population continued increasing until it reached a size of more than $10^{-12} \mathrm{cfu}$ within 15 days after inoculation (dai; Figure 1). That is, colonization along the leaf was fast. Initially, Xoo bacterial cells were concentrated in 


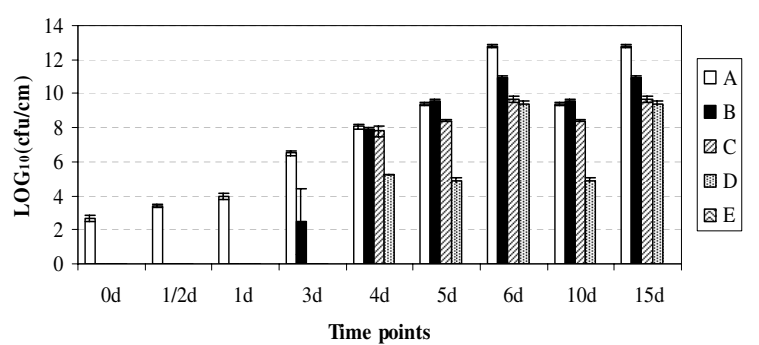

Figure 1 In planta quantification of bacteria. Bacterial growth in 8week old rice variety Nipponbare, in sections $A, B, C, D$, and $E$ of the leaf at 0 and $12 \mathrm{~h}$, and $1,3,6,10$, and 15 days after inoculation. The experiment was repeated three times with three leaves per time point. Error bars indicate standard errors

the first $2 \mathrm{~cm}$ behind the inoculation point but, within 3 dai, they were found in section B. By day 6 , the bacterium had colonized more than $8 \mathrm{~cm}$, reaching section D. Levels of Xoo MAI1 populations increased gradually from sections $\mathrm{A}$ to $\mathrm{D}$, reaching $10^{-9}$ to $10^{-13} \mathrm{cfu}$ per section of leaf by 15 dai. By that time, visible lesions were about $10 \mathrm{~cm}$ long. We selected three time points (1,3, and 6 dai) and the first 2-cm lesion to perform bacterial RNA extractions from leaf tissues for subsequent microarray experiments. Possible genomic DNA contamination was tested by PCR, using primers corresponding to the genomic region flanking the $h r p X$ (hypersensitive reaction and pathogenesis) gene and purified RNA as PCR template. No DNA contamination was found (data not shown).

\section{Differentially expressed genes were identified at late stages of infection}

The DNA microarray constructed consists of about 4708 randomly selected clones. The quality of PCR amplification was verified for $20 \%$ of the amplified genes (1330 clones), with sizes ranging from 600 to $900 \mathrm{bp}$. The arrays were hybridized with Cy labelled cDNA probes prepared from total RNA from plant-grown bacteria at 1, 3, and 6 dai, or from bacteria cultured in media and re suspended in water.

We used bootstrap analysis with SAM to identify differentially expressed genes. Significance Analysis of Microarrays (SAM) calculates the fold change and significance of differences in expression. The delta-delta Ct values ranged from 1.21 to 2.37 for each time point. The false significant number (FSN) ranged between 0.80 and 4.99, while the false discovery rate (FDR) ranged from 0.25 to 3.80 . Of the 4708 Xoo strain MAI1 clones analysed, 710 genes were found to be differentially expressed with 407 up- and 303 down-regulated. The proportions of differentially expressed genes (up- or down-regulated) remained relatively constant over the first 3 days after inoculation but had changed markedly by day 6 , with the proportions reversing (Table 1).

\section{Identification of differentially expressed genes}

A total of 710 differentially expressed genes were one-end sequenced. After eliminating for low quality and vector contamination, 535 sequences were obtained. Insert size varied between 112 and $1902 \mathrm{bp}$, with an average of 660 bp. The initial data set of 535 good sequences was reduced to 147 unique consensus sequences, comprising 57 contigs and 90 singletons. To annotate the Xoo MAI1 non-redundant sequences, we used the Gene Ontology (GO) functional classification scheme [31]. Most functionally assigned non-redundant sequences (52\%) fell into two classes: proteins with unknown function and biological process unknown (Figure 2). Mobile genetic elements, such as phage-related and IS elements, were well represented (18\%). Secretion, transport, and binding proteins, together with virulence-related sequences, represented $14 \%$ of the differentially regulated genes (Figure 2).

\section{Thirty genes are specifically regulated}

The set of 147 unique consensus sequences differentially expressed during infection, was searched against the genomes of all available sequenced strains of $X$. oryzae

Table 1: Statistical summary of Significance Analyses of Microarrays (SAM)

\begin{tabular}{llll}
\hline Gene expression & Days after inoculation & & $\mathbf{6}$ \\
& $\mathbf{1}$ & & 2.12 \\
\hline Delta-delta Ct value & 1.21 & 0.80 & 2.37 \\
False significant number (FSN) & 4.99 & 0.48 & 1.35 \\
False discovery rate (FDR) & 3.80 & $96(40 \%)$ & 0.25 \\
Up-regulated & $58(47 \%)$ & $43(60 \%)$ & $253(57 \%)$ \\
Down-regulated & $66(53 \%)$ & & $194(43 \%)$ \\
\hline Total & 124 & 239 & 447 \\
\hline
\end{tabular}

The number of up- and down-regulated genes that are differentially expressed at different time points during infection by Xanthomonas oryzae pv. oryzae, African strain MAl1. 
Table 2: Differentially expressed genes that are specific to the African strain MAI1 of Xanthomonas oryzae pv. oryzae (Xoo)

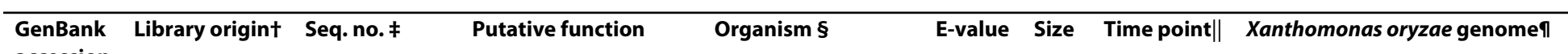

accession

$\begin{array}{llllllll}1 & 3 & 6 & \text { MAFF } 311018 & \text { KACC } 10331 & \text { PXO 99A } & \text { BLS 256 } & \text { BAI3 }\end{array}$

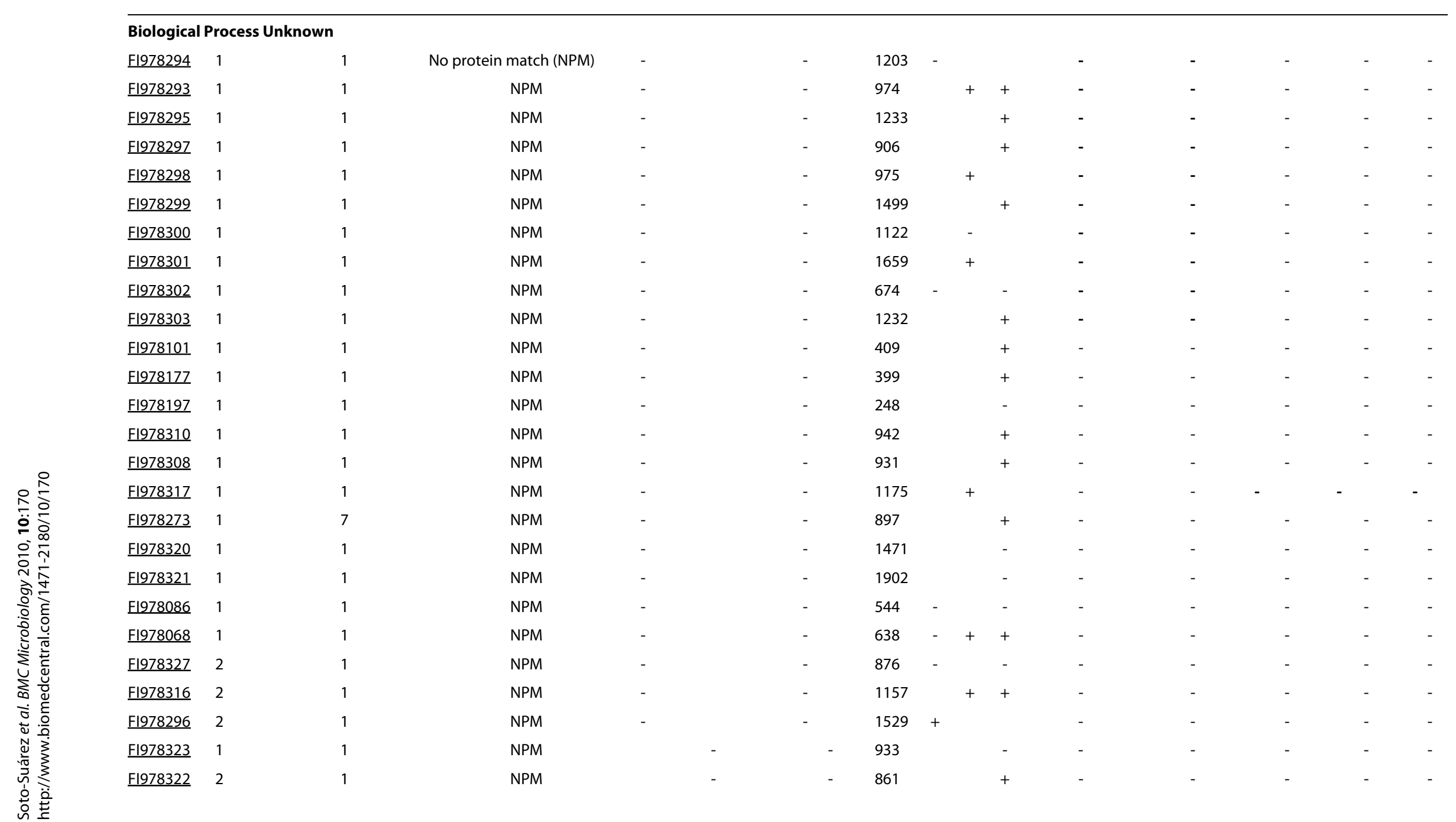


Table 2: Differentially expressed genes that are specific to the African strain MAI1 of Xanthomonas oryzae pv. oryzae (Xoo) (Continued)

\begin{tabular}{|c|c|c|c|c|c|c|c|c|c|c|c|c|}
\hline \multicolumn{13}{|c|}{ Hypothetical protein } \\
\hline$\underline{F I 978307}$ & 2 & 1 & $\begin{array}{l}\text { Hypothetical protein } \\
\text { XCC2965 }\end{array}$ & $\begin{array}{l}\text { Xcc strain ATCC } \\
33913\end{array}$ & $3.0 \mathrm{E} 12$ & 835 & - & - & - & - & - & - \\
\hline$\underline{F 1978239}$ & 1 and 2 & 2 & $\begin{array}{l}\text { Hypothetical protein } \\
\text { XCC2966 }\end{array}$ & $\begin{array}{l}\text { Xcc strain ATCC } \\
33913\end{array}$ & 7.0E 11 & 244 & + & - & - & - & - & - \\
\hline \multicolumn{13}{|c|}{ Phage-related and IS elements } \\
\hline$\underline{F I 978271}$ & 1 & 7 & $\begin{array}{l}\text { Gene transfer agent (GTA) } \\
\text { like protein }\end{array}$ & $\begin{array}{l}\text { Parvibaculum } \\
\text { lavamentivorans } \\
\text { strain DS } 1\end{array}$ & $8.0 \mathrm{E} 50$ & 788 & + & - & - & - & - & - \\
\hline \multicolumn{13}{|c|}{ Metabolism } \\
\hline$\underline{F l 978324}$ & 1 & 1 & Haemolysin III & $X c c$ & $5.0 \mathrm{E} 17$ & 853 & - & - & - & - & - & - \\
\hline
\end{tabular}

TSSH library and/or libraries in which the clone was identified, where 1 corresponds to SSH library Xoo strain M1/PXO86, and 2 to SSH library Xoo strain M1/Xoc BLS256.

$\ddagger$ Number of sequences by contig, where 1 indicates singleton.

$\S X c c$ is Xanthomonas campestris pv. campestris; Xoo is Xanthomonas oryzae pv. oryzae.

$\|$ Time point, in days after inoculation, where + indicates up-regulated, and - indicates down-regulated.

१Xanthomonas oryzae genomes, where + indicates presence of gene homologues to Xoo MAl1 in the genome analysed, and - indicates absence. 

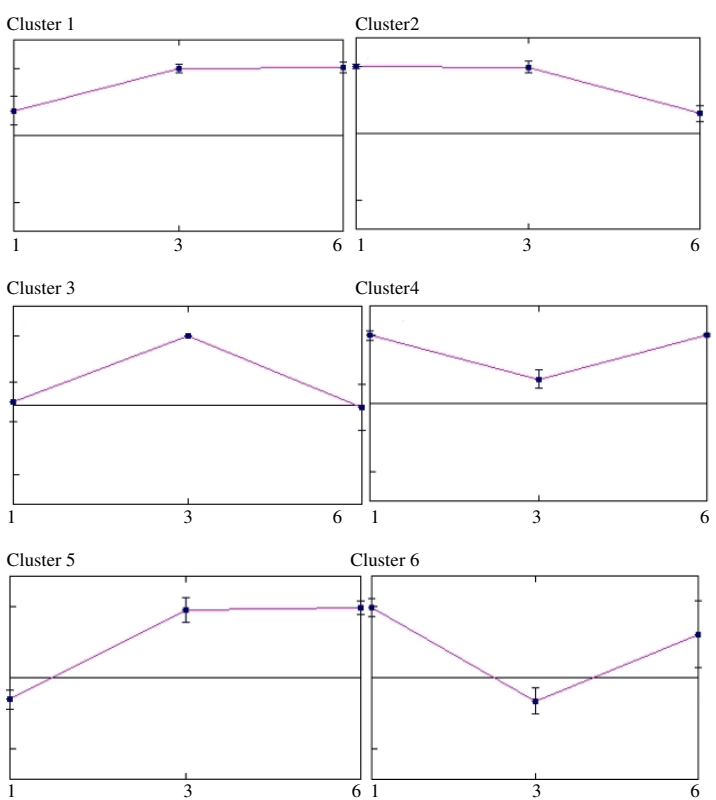

Cluster 7

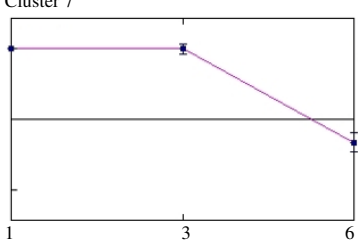

Figure 3 Clusters of transcripts based on patterns of differential expression. Differentially expressed transcripts were clustered, using the $k$-means method. The mean expression levels of genes in each cluster are shown as a centroid graph. Error bars represent standard deviations of expression within the cluster. Seven clusters were created, with clusters $1,2,3$, and 4 comprising up-regulated genes and clusters 5, 6, and 7 comprising down-regulated genes at 1, 3, and 6 dai, respectively. The $x$ axis represents time-points during infection $(1,3$, and 6 dai) and the $y$ axis the expression level.

$X$. axonopodis pv. citri (Xac), X. campestris pv. campestris $(X c c)$, and others $[35,36,40,44]$. Inside plant tissues, biofilms are thought to contribute to virulence by blocking sap flow in the xylem vessels and promoting plant wilt [39]. The up-regulated genes involved in biofilm formation and pathogenicity were identified in Xylella fastidiosa through microarray analysis, which compared cells growing in a biofilm with planktonic cells [45]. In Xoo MAI1, we identified several of these genes as corresponding to type IV pili genes (e.g. FI978319) and the fimbrial assembly protein (e.g. FI978267) (Additional file 1, Table S1). Given that Xoo, like Xylella fastidiosa, is a restricted vascular pathogen, the induction of genes related to adhesion and motility suggests a role in biofilm formation and vascular colonization. The Xoo MAI1 strain regulates the expression of a group of genes for adherence and biofilm formation in the nutrient-limited environment of xylem in rice. This group's role in pathogenicity should be investigated.

Among the up-regulated genes in the Xoo MAI1 strain, we found one cellulase (FI978181) and one xylanase (FI978325) gene activated at 3 dai (cluster 1). Using an SSH approach, Qi et al. [46] identified the unique Fibrobacter intestinalis genes coding for plant cell-wall hydrolytic enzymes. More than 40 cellulases play a major role in F. intestinalis plant cell-wall degradation. An xylanase of Xoo was differentially expressed in planta [47]. Both enzymes (cellulase and xylanase) may play a similar role in Xoo MAI1 in degrading rice cell walls, thus facilitating pathogen multiplication.

\section{Major virulence genes are up-regulated in planta}

Five classes of virulence genes were found regulated during infection. They corresponded to three genes related to the avrBs3/pth family (FI978282, M1P3I15, and AF275267), a leucin-rich protein (BAE68417), a virulence regulator (FI978260), and a xopX (ACD57163) and $h r p F$ gene (FI978263). Most of these major virulence genes fell into cluster 1 , corresponding to genes that are activated after 3 dai. Xoo pathogenicity is highly dependent on the type III secretion system (TTSS) injecting effector proteins into the eukaryotic host cell [48]. Most knowledge on TTSS in Xoo is based on studies of the large AvrBs3/ pthA family of Xanthomonas effector proteins [49]. This family includes proteins with avirulence activities, virulence functions, or both [48]. It includes the well-characterized AvrXa7 protein, which plays a role in bacterial growth and lesion development in rice [50,51]. Genes avrXa7 (AF275267) and xopX (ACD57163) are up-regulated at both 3 and 6 dai. The $x o p X$ gene encodes a TTSS effector protein and contributes to the virulence of $X$. campestris pv. vesicatoria on hosts pepper and tomato [52]. XopX targets the innate immune response, resulting in enhanced plant disease susceptibility [52]. The XopX protein from $X c c$ is required for full virulence, as shown by the $X c c N$ mutant that produced weaker disease symptoms than the wild-type strain [53].

The HrpF protein is probably inserted into the plantcell membrane and may be required for the bacterium's type III effector proteins to enter host cells [54]. As a bacterial translocon, HrpF would therefore be in direct contact with the plant-cell membrane and even possibly subjected to the plant's surveillance mechanisms while it mediates effector protein delivery across the host-cell membrane. To demonstrate that HrpF is required for pathogenicity, Sugio et al. [55] used Xoo hrpF mutants, which had a reduced ability to either grow within rice plants or cause lesions. For the Xoo MAI1 strain, we found a $h r p F$ gene that was differentially expressed at 3 dai during infection. The activation of different genes encoding proteins secreted by TTSS ( $h r p F, a v r X a 7$, and 
xopX genes) during Xoo MAI1-rice interaction was consistent with TTSS being essential for Xoo pathogenicity.

\section{Expression of IS elements in Xoo MAI1 during infection}

Insertion sequence (IS) elements have recently been shown to play a role in plant pathogenicity [56-59]. These elements may inactivate genes on insertion or activate and/or enhance the expression of nearby genes $[57,60,61]$. One characteristic of the Xoo genomes sequenced to date is the accumulation of many IS elements, representing as much as $10 \%$ of the Xoo genome size [23]. In Xanthomonas spp., virulence and pathogenicity islands are commonly associated with mobile genetic elements such as phages and transposons [56,58]. By comparing gene expression of both Xoo and Xoc grown in enriched versus minimal medium, Seo et al. [16] determined that IS elements are differentially expressed in minimal medium.

In our study, we identified 27 IS elements in Xoo MAI1 that are up- or down-regulated in planta. Most of these IS elements belong to cluster 1, corresponding to genes that are activated after 3 dai. Twelve elements were classified into the following IS families: IS30 (4 elements), IS5 (7), and IS3 (1), with 15 IS elements unclassified. Members of the IS5 family have been reported previously in bacterial pathogens and it has been speculated that expression of some pathogenicity genes might be controlled by the expression/insertion of IS5 family elements $[58,62,63]$. Expression of IS5 members in the neighboring region of their hrp gene cluster was observed in Pseudomonas syringae [64] It has been also demonstrated that IS elements (among them some IS5 family members) can act as a mobile switch for the downstream genes, creating new transcriptional promoters and increasing the expression levels of downstream genes [65]. Members of the IS3 and IS30 families have also been reported in bacterial pathogens, some of them controlling the expression of other genetic elements $[60,66]$. The expression of IS elements in Xoo MAI1 in planta suggests that these elements may play a significant role in bacterial pathogenicity or may be associated with genes related to pathogenicity.

To establish a correlation between the presence of IS elements and adjacent genes differentially expressed in MAI1, we used the draft genome of Xoo African strain BAI3 (Genoscope project 154/AP 2006-2007 and our laboratory, 2009, unpublished data) and the published genome of Xoo strain MAFF311018 [22]. We compared the location of the 147 Xoo MAI1 differentially expressed genes with the presence of adjacent IS elements in the Xoo BAI3 and MAFF311018 genomes. For this, homologous sequences of IS elements, found as differentially expressed in the Xoo strain MAI1, were first identified in the BAI3 draft genome. We then extracted $10 \mathrm{~kb}$ from each of up- and downstream flanking regions of IS ele- ments. BLAST searches were performed against these flanking regions, using the Xoo MAI1 non-redundant set of sequences. For the sequences located within $20 \mathrm{~kb}$ of sequences flanking the IS elements, we compared the relative distance of each sequence to the IS element in BAI3 with the relative distance of their respective homologues in the Xoo MAFF311018 genome (Table 3).

Results showed that homologues of the 11 selected Xoo MAI1 differentially expressed genes are located in the vicinity of IS elements in BAI3 genome, within the same 20-kb region (Table 3). In the Xoo MAFF311018 genome, Xoo MAI1 differentially expressed genes are not located in a vicinity of $20 \mathrm{~kb}$ of the IS elements. Given that the African Xoo strain BAI3 is more closely related to Xoo MAI1 than Xoo MAFF311018, a similar organization of IS elements and presence of neighbour genes are expected for MAI1. Correlation between differential expression of IS elements, genome location, and role played in the control of expression of nearby genes in African Xoo strains need further study.

Validation of differentially expressed genes, using QRT-PCR To validate the Xoo MAI1 microarray results, QRT-PCR was performed on a set of 14 genes of different functions and which were up- or down-regulated during infection. Table 4 lists the primers, putative function, and average fold-change expression of genes used for QRT-PCR validation. The genes selected for QRT-PCR correspond to four hypothetical proteins (FI978067, FI978252, FI978305, and FI978328), one gene showing no similarity to known proteins (FI978310), two putative transposases (FI978288 and FI978099), two genes related to transport and motility (FI978259 and FI978319), one hrpF gene (FI978263), and one avirulence protein from the AvrBs3/ pthA family (F1978282), the avr/pth14 gene (M1P3115), the $x o p X$ gene (ACD57163), and the avrXa7 gene (AF275267). Figure 4 shows five genes out of the 14 tested that were up-regulated by QRT-PCR and having a larger than 4-fold change. Of the 14 genes selected according to the microarray data (Table 4), 13 were up-regulated and 1 (F1978067) was down-regulated. The QRT-PCR results supported these data, and also showed that the gene expression pattern was identical for all genes tested, except two (FI978259 and FI978319). Gene expression values, however, differed between microarrays and QRTPCR. As shown in Figure 4, the expression values for the five genes FI978252, FI978263, FI978328, AF275267, and ACD57163 were higher in QRT-PCR than for microarray, indicating that QRT-PCR may be more sensitive than microarray analysis. The $x o p X$ gene (ACD57163) was highly up-regulated in Xoo strain MAI1 in planta, indicating that induction of this gene is important during interaction between Xoo strain MAI1 and rice. These five genes belonged to cluster 1 . 
Table 3: Homologues of genes in strain MAI1 found near IS elements in the BAI3 genome

\begin{tabular}{|c|c|c|c|c|}
\hline \multirow[b]{2}{*}{$\begin{array}{l}\text { Flanking sequence of } \\
\text { IS element }\end{array}$} & \multirow[b]{2}{*}{ Genes in vicinity } & \multirow[b]{2}{*}{ Putative function } & \multicolumn{2}{|c|}{$\begin{array}{l}\text { Relative distance (kb) between differentially } \\
\text { expressed genes and IS elements in genome: }\end{array}$} \\
\hline & & & BAI3 & MAFF311018 \\
\hline FI978233 & & & $10001 . .10132$ & $920135 . .920004$ \\
\hline \multirow[t]{9}{*}{$\begin{array}{l}\text { ISXo8 transposase (IS5 } \\
\text { family) }\end{array}$} & FI978262 & $\begin{array}{l}\text { ISXo8 transposase (IS5 } \\
\text { family) }\end{array}$ & -2.0 & -3723 \\
\hline & FI978083 & Putative transposase & +8.2 & +621 \\
\hline & M1P4B2 & No protein match & +1.2 & -3796 \\
\hline & FI978246 & Transposase & +6.3 & -1089 \\
\hline & FI978279 & $\begin{array}{l}\text { ribonucleoside- } \\
\text { diphosphate } \\
\text { reductase, beta } \\
\text { subunit }\end{array}$ & -0.9 & +153 \\
\hline & FI978268 & No protein match & +7.8 & +761 \\
\hline & FI978290 & $\begin{array}{l}\text { dTDP-glucose } 4,6- \\
\text { dehydratase }\end{array}$ & -10.1 & +144 \\
\hline & FI978285 & $\begin{array}{l}\text { hypothetical protein } \\
\text { XOO1934 }\end{array}$ & -1.2 & +150 \\
\hline & FI978270 & Putative transposase & -3.8 & +757 \\
\hline F1978246 & & & $10001 . .10299$ & $2009657 . .2009789$ \\
\hline transposase & FI978181 & Cellulase & -5.5 & +1728 \\
\hline F1978274 & & & 13384...14161 & 14199973..1420912 \\
\hline $\begin{array}{l}\text { ISXoo15 transposase } \\
\text { (IS30 family) }\end{array}$ & FI978084 & Putative transposase & +7.8 & +13.8 \\
\hline \multicolumn{5}{|c|}{$\begin{array}{l}\text { Homologues of IS elements, found as differentially expressed in the African strain MAI1 of Xanthomonas oryzae pv. oryzae (Xoo) were } \\
\text { identified in the Xoo BAI3 draft genome. Extractions (10 kb) were made from up- and downstream flanking regions of IS elements. BLAST } \\
\text { searches were performed locally, using the MAI1 differentially expressed genes. For the sequences located within the 20-kb sequence } \\
\text { flanking the IS elements, the relative distance of each sequence to the IS element in BAI3 was compared with the relative distance of their } \\
\text { respective homologues in the Xoo MAFF311018 genome. The designation + indicates upstream location of the sequence relative to the IS } \\
\text { element, and the designation - indicates downstream location. For IS elements, gene locations within the 20-kb sequence flanking the IS } \\
\text { element in BAI3 and within the genome of Xoo MAFF311018 are presented. }\end{array}$} \\
\hline
\end{tabular}

\section{Conclusions}

Sustainable control measures for bacterial blight in Africa will depend on understanding and characterizing those of the microbe's genes involved in the rice-Xoo interaction. We therefore focused our study on analysing and characterizing Xoo MAI1 at the transcriptional level. For this we constructed a Xoo MAI1 SSH array, performed in planta gene expression analysis and selected and validated by QRT-PCR various gene expressions to generate robust and reliable data. Although the SSH microarray may not be as sensitive as QRT-PCR for some genes, results included several candidate genes whose regulation and function will need to be elucidated to better understand the Xoo-rice interactions.

Our study shows that the regulation of gene expression in the Xoo strain MAI1 is controlled at different time points during pathogen infection. We identified conserved mechanisms for which some were reported in other Xoo-plant interactions but not yet described for African strains. We also identified differentially regulated genes specific to the Xoo strain MAI1. Several homologues of Xoo MAI1 differentially expressed genes were located in the vicinity of IS elements in the Xoo BAI3 genome. The role played by these IS elements in controlling neighbouring-gene expression needs to be elucidated. More data on African Xoo strains also need to be generated. Recently, the sequencing of various African $X o o$ and Xoc strains has been initiated at our laboratory and others. With this information, the full-length cDNA of desired genes can be easily obtained and their specific functions in pathogenicity studied, using available gene knockout technology. Functional characterization of the proteins/genes related to virulence will be of particular importance in understanding the complex interaction between Xoo MAI1 and rice. Our work constitutes a significant contribution towards the biology of an emerging 


\begin{tabular}{|c|c|c|c|c|c|c|c|c|c|c|c|}
\hline & \multirow[b]{2}{*}{ Gene } & \multirow[b]{2}{*}{ Putative function } & \multirow[b]{2}{*}{ Primer sequence } & \multirow[b]{2}{*}{ Size, bp } & \multirow[b]{2}{*}{$\mathrm{AT},{ }^{\circ} \mathrm{C}$} & \multicolumn{3}{|l|}{ Array } & \multicolumn{3}{|c|}{ QRT-PCR } \\
\hline & & & & & & 1 dpi & 3 dpi & $6 \mathrm{dpi}$ & 1 dpi & 3 dpi & $6 \mathrm{dpi}$ \\
\hline & \multirow[t]{2}{*}{ F1978319 } & Type IV pilin & 5' CTAACCGGCTGAGCTATTCG & 166 & 60 & 0,0 & 0,0 & 1,3 & 2,7 & 2,9 & 2,0 \\
\hline & & & 3' CAGCCAAGCCAAAGACAAGT & & & & & & & & \\
\hline & \multirow[t]{2}{*}{ FI978328 } & probable TonB-dependent receptor & 5' CGCACTAATCGCATTCTCAA & 167 & 60 & 0,0 & 29,0 & 11,7 & 29,9 & 69,0 & 22,5 \\
\hline & & & 3' AAACGGCGGATGTAGAACAG & & & & & & & & \\
\hline & \multirow[t]{2}{*}{ F1978288 } & putative transposase & 5' GCAGAACGTTGGGAACACTT & 156 & 60 & 0,0 & 1,7 & 0,8 & 0,5 & 0,4 & 1,0 \\
\hline & & & 3' CAGATTCGACAGCGCAAATA & & & & & & & & \\
\hline & \multirow[t]{2}{*}{ FI978282 } & avirulence protein AvrBs3/pth family & 5' AAGAGGAACTCGCATGGTTG & 167 & 60 & 0,0 & 0,6 & 1,3 & 0,7 & 0,6 & 1,6 \\
\hline & & & 3' TTGAACGCATCTGTCTACCG & & & & & & & & \\
\hline & \multirow[t]{2}{*}{ F1978099 } & putative transposase & 5' TCGTTTTGTTAGCCGCTCTT & 188 & 60 & 0,0 & 0,9 & 1,4 & 0,0 & 0,8 & 1,6 \\
\hline & & & 3' GACGCACATTGCACTTTGAT & & & & & & & & \\
\hline & \multirow[t]{2}{*}{ M1P3I15 } & Avr/Pth14 (avr/pth14) gene & 5' AGGTACGAGGCCTCACTGAA & 140 & 60 & 0,0 & 1,4 & 1,9 & 3,2 & 3,4 & 8,1 \\
\hline & & & 3' CAATTCCCTATCCCGAGGAG & & & & & & & & \\
\hline & \multirow[t]{2}{*}{ FI978263 } & HrpF protein & 3' GGGCTAACAATCACCAGAGC & 157 & 60 & 0,0 & 5,0 & 9,8 & 8,3 & 26,7 & 12,5 \\
\hline & & & 5' CACGTTTTCGGGATTCAAGT & & & & & & & & \\
\hline & \multirow[t]{2}{*}{ F1978252 } & hypothetical protein XOO0776 & 5' AGAAGTTGCAGGCCAAAGAA & 150 & 60 & 0,0 & 20,0 & 12,3 & 4,3 & 47,5 & 24,9 \\
\hline & & & 3' CGCAGGTGACAAACAAAAGA & & & & & & & & \\
\hline & \multirow[t]{2}{*}{ FI978310 } & - & 5' AATGGATCAGTTGGGTTGGA & 224 & 60 & 0,0 & 0,0 & 1,5 & 0,0 & 1,2 & 1,1 \\
\hline & & & 3' GAGGTACGCTtcgaCGTTTC & & & & & & & & \\
\hline 욜 & \multirow[t]{2}{*}{ FI978259 } & ATP-binding protein of $A B C$ transporter & 5' TCAGCTCATTTCACGTCAGG & 215 & 60 & 0,0 & 0,0 & 1,6 & 2,5 & 1,7 & 1,6 \\
\hline$\check{0}$ & & & 3' CAGAGCAGGGTGTGTAAGCA & & & & & & & & \\
\hline$\div \frac{\infty}{\pi}$ & \multirow[t]{2}{*}{ F1978067 } & conserved hypothetical protein & 5' GCATATAGCTCCGAGGCAAC & 160 & 60 & 0,0 & $-2,2$ & 0,0 & $-0,8$ & $-2,8$ & $-0,2$ \\
\hline$\overline{\frac{D}{1}} \frac{1}{n}$ & & & 3' GGTTTCCCCATTCGGATATT & & & & & & & & \\
\hline के ક & \multirow[t]{2}{*}{ F1978305 } & hypothetical protein xccb100_3708 & 5' AGGAGCCAAGGCAATTAACA & 170 & 60 & 0,0 & 0,0 & 0,5 & 0,5 & 0,6 & 1,2 \\
\hline$\underline{\xi}$ & & & 3' TGAGGAGTCTGGGAAGTTGG & & & & & & & & \\
\hline بَ & \multirow[t]{2}{*}{ ACD57163 } & XopX effector protein & 5' TTGTTCCTGCCATTGGAAAT & 150 & 60 & 10,0 & 14,7 & 11,0 & 198,5 & 49,0 & 43,3 \\
\hline 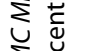 & & & 3' GATGCTGCTCCAGAGAAAGG & & & & & & & & \\
\hline$\sum_{\infty}^{\infty} \frac{\tilde{v}}{0}$ & \multirow[t]{2}{*}{ AF275267 } & avirulence protein gene (avrXa7) & 5' GCACAGCAATCTITCGAGGT & 172 & 60 & 0,0 & 7,2 & 3,0 & 9,8 & 12,3 & 4,8 \\
\hline క气 & & & 3' CATCTTGTTCCCACATCACG & & & & & & & & \\
\hline
\end{tabular}

putative function; average of fold-change expression, gene product sizes, and annealing temperatures (AT) are indicated. 


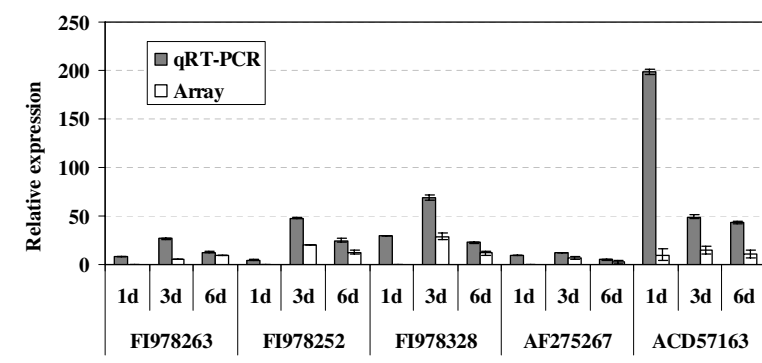

Figure 4 Comparing expression of genes through microarray and QRT-PCR assays. We used real-time PCR analysis to confirm the differential expression of 14 genes of the African strain MAl1 of Xanthomonas oryzae pv. oryzae. The genes represented various biological functional classes of interest. Although fold change in gene expression was generally higher for QRT-PCR than for the microarray, good correlation existed between the two data sets. A subset of 5 genes corresponding to xopX (ACD57163), HrpF protein (F1978263), hypothetical proteins (FI978252 and FI978328), and the avrXa7 gene (AF275267) showing a fold-change higher than 10 in QRT-PCR is illustrated in the figure. Three replicates were analysed in both microarray and QRT-PCR experiments. Vertical bars represent standard deviations.

and devastating pathogen under a specific, but insufficiently studied, environment in West Africa.

\section{Methods}

\section{DNA microarray construction}

Two subtracted DNA libraries (SSH) were previously constructed in our laboratory and partially characterized [28]. For the first library (MAI1-PXO86), the tester was the African Xoo MAI1 (race A3) and the driver the Philippine Xoo PXO86 (Phil race 2). For the second library (MAI1-BLS256), the same tester was used, with Xoc BLS256 being the driver. We randomly selected 2112 clones from MAI1-PXO86 library and 2304 from MAI1BLS256. From the MAI1-PXO86 SSH library, we selected another 88 clones that represented a non-redundant set of sequences selected from a previous analysis of 265 sequences from that library [28]. Several controls (clones from genes of other bacteria, fungi, rice, and humans) were also included. Inserts from each DNA clone were PCR-amplified directly from bacteria. Amplification reactions were performed in 96-well plates, with each well carrying a $50-\mu \mathrm{l}$ volume containing $0.2 \mu \mathrm{M}$ of each primer (T7 and SP6), $200 \mu \mathrm{M}$ of each dNTP, $1 \times$ PCR buffer, and 1.25 units of Taq polymerase (AmpliTaq DNA polymerase, Promega Corporation). An MJ Research thermal cycler was used for 35 PCR cycles, as follows: $95^{\circ} \mathrm{C}$ for $45 \mathrm{~s}, 56^{\circ} \mathrm{C}$ for $45 \mathrm{~s}$, and $72^{\circ} \mathrm{C}$ for $1 \mathrm{~min}$. We also amplified a selected set of conserved effector and hrp genes (e.g. XopX, avrXa7, XopD, avrRxv, avrXv3, hpaF, and $h r p x$ ), housekeeping genes, and other conserved bacterial genes from genomic DNA of Xoo MAI1. Random PCR samples were visualized on agarose gels. All PCR products were transferred to a 384-well plate and a volume of $2 \times$ betaine solution was added. The PCR products were arrayed once on poly-L-lysine slides (TeleChem International, Inc., Sunnyvale, CA, USA), using an $\mathrm{SPBIO}^{\mathrm{m}}$ Microarray Spotting Station (MiraiBio, Inc., Alameda, CA, USA). The microarray contained 4708 elements.

\section{Bacterial inoculation and quantification}

The Xoo strain MAI1 was grown on PSA medium $\left(10 \mathrm{~g} \mathrm{l}^{-1}\right.$ peptone, $10 \mathrm{~g} \mathrm{l}^{-1}$ sucrose, $1 \mathrm{~g} \mathrm{l}^{-1}$ glutamic acid, $16 \mathrm{~g} \mathrm{l}^{-1}$ agar, and $\mathrm{pH}$ 7.0) for 2 days at $30^{\circ} \mathrm{C}$. The bacterial cells were resuspended in sterilized water at an optical density of 600 $\mathrm{nm}\left(\mathrm{OD}_{600}\right.$ ) (about $10^{-9} \mathrm{cfu} \mathrm{ml}^{-1}$ ). Bacterial blight inoculation was carried out on the two youngest, fully expanded leaves on each tiller of 6-week-old rice plants (var. Nipponbare), using the leaf-clipping method [67]. Experiments were conducted under greenhouse conditions at $26^{\circ} \mathrm{C}$ and $80 \%$ relative humidity.

We determined Xoo MAI1 multiplication in planta at seven time points after infection by leaf clipping ( 0 and 12 $\mathrm{h}$, and $1,3,6,10$, and 15 days after inoculation) in 8-weekold plants of the susceptible rice cultivar Nipponbare. The number of cells in the leaves was determined at the top $10 \mathrm{~cm}$ of each leaf which was cut into five $2-\mathrm{cm}$ sections, and labelled A, B, C, D, and E, with A being the inoculation point. The leaf pieces were then ground in 1 $\mathrm{ml}$ of sterilized water. Serial dilutions were made and spread onto PSA agar plates. The plates were incubated at $28^{\circ} \mathrm{C}$ until single colonies could be counted. The number of colony-forming units ( $\mathrm{cfu}$ ) per leaf (equivalent to about $2 \mathrm{~cm}^{2}$ ) was counted and standard deviations calculated. The experiment was repeated independently three times.

\section{RNA extraction}

To obtain RNA from cells growing in planta, 30 rice leaves were inoculated by the leaf-clipping method. At each time point, leaves extending $2 \mathrm{~cm}$ from the tip were collected and, to facilitate exudation of bacterial cells, vortexed for $30 \mathrm{~s}$ with RNAprotect Bacteria Reagent (QIAGEN, Inc., Courtaboeuf, France). The leaves were removed and bacterial cells were collected in a $15-\mathrm{ml}$ tube by centrifuging at $4000 \mathrm{rpm}$ for $30 \mathrm{~min}$ at $4^{\circ} \mathrm{C}$. Total RNA extraction and DNase treatment were conducted, using the RNeasy Mini Kit according to the manufacturer's recommendations (QIAGEN, Inc.). To obtain RNA from bacterial cells, bacterial cultures were grown on PSA medium at $28^{\circ} \mathrm{C}$ until the early stationary phase. They were then re-suspended in $15 \mathrm{ml}$ sterilized Milli-Q water, adjusted to $\mathrm{OD}_{600}$ of 0.2 (about $10^{-8} \mathrm{cfu} \mathrm{ml}^{-1}$ ), pelleted by centrifuging, and transferred to $1.5-\mathrm{ml}$ tubes. Total RNA and DNase I treatments were performed as described above. The RNA quality was verified both by agarose-gel electrophoresis and by PCR (for presence of 
genomic DNA), using the genomic region flanking the hrpX gene as control and purified RNA as the PCR template. About $1 \mu \mathrm{g}$ of Xoo MAI1 total RNA, obtained from cells grown in culture medium or in planta and treated with DNase I, were used individually to synthesize singlestranded cDNA. The SMART ${ }^{\mathrm{ma}}$ PCR cDNA Synthesis Kit (BD Biosciences Clontech) was used, following the manufacturer's instructions. The cDNA was then quantified, using the PicoGreen reagent (Invitrogen, Ltd., Paisley, UK), an ultra-sensitive, fluorescent, and nucleic dye.

\section{DNA microarray hybridization}

Fluorescent-labelled probes were prepared, following the Klenow labelling method (indirect labelling). Briefly, 500 ng of cDNA were labelled, using $1 \mu \mathrm{l}$ of either Cy3- or Cy5-dUTP (Amersham Pharmacia Biotech, Little Chalfont, UK), 10 U Exonuclease-Free Klenow (USB Corporation, Cleveland, $\mathrm{OH}, \mathrm{USA})$, and $3 \mu \mathrm{g}$ random primers (Invitrogen Life Technologies, Carlsbad, CA, USA), and incubated $2 \mathrm{~h}$ at $37^{\circ} \mathrm{C}$. Unincorporated nucleotides were removed, using a QIAquick PCR Purification Kit (QIAGEN, Inc.). Cleaned probes were concentrated in a speedvac (Eppendorf Vacufuge Concentrator 5301, Hamburg, Germany).

Before hybridization, glass slides were snap-dried on a $95^{\circ} \mathrm{C}$ heating block for $10 \mathrm{~s}$. DNA was crosslinked to the slides, using $65 \mathrm{~mJ}$ of 254-nm UV-C radiation from a Stratalinker UV Crosslinker (model 2400, Stratagene, La Jolla, CA, USA). Slides were incubated $2 \mathrm{~h}$ at $70^{\circ} \mathrm{C}$ and pre-hybridized with $1 \% \mathrm{BSA}, 5 \times \mathrm{SSC}$ buffer, and $0.1 \%(\mathrm{w} /$ v) SDS for $45 \mathrm{~min}$ at $54^{\circ} \mathrm{C}$. The hybridization mixture

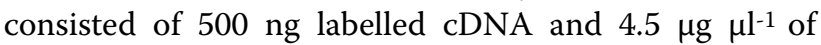
salmon sperm DNA (Invitrogen Life Technologies) in a final volume of $35 \mu \mathrm{l}$. This volume was mixed with $35 \mu \mathrm{l}$ of $2 \times$ hybridization buffer ( $1 \times$ formamide, $1 \times \mathrm{SSC}$, and $0.04 \times \mathrm{SDS})$. The mixture was denatured at $95^{\circ} \mathrm{C}$ for $2 \mathrm{~min}$ and transferred to ice. The hybridization mixture was applied to a microarray slide, transferred immediately to a hybridization chamber (Corning, Inc., Lowell, MA, USA), and incubated overnight (15-17 h) at $42^{\circ} \mathrm{C}$. The slide was then washed for 5 min successively in each of $2 \times$ $\mathrm{SSC}, 0.1 \%(\mathrm{w} / \mathrm{v}) \mathrm{SDS}$ at $54^{\circ} \mathrm{C}, 1 \times \mathrm{SSC}$, and $0.1 \times \mathrm{SSC}$ at room temperature. Slides were immediately dried by centrifuging at $1000 \mathrm{rpm}$ for $4 \mathrm{~min}$.

At each time point, cDNA, obtained from bacteria used as inoculum and re-suspended in water (time 0), was compared with bacteria recovered from inoculated plants at 1,3 , and 6 dai. The comparisons made were $0-1,0-3$, and 0 - 6 dai. To maximize the statistical reliability of the data, three biological replicates were carried out.

In addition, for each time point comparison and each biological replicate, three technical replicates (cDNA obtained from the same mRNA extraction) were used for hybridization. For one of the three technical replicates, the labelling of the two cDNA samples with either Cy5 or $\mathrm{Cy} 3$ fluorescent dye was reversed to prevent potential dye-related differences in labelling efficiency. Overall, 27 images were analysed, 9 for each time point during Xoo infection. The nine data points obtained for each gene were used in the analyses.

\section{Microarray data analysis}

The slides were scanned, using a chip reader/scanner (Virtek Vision International, Inc., Waterloo, ON, Canada). The signal was initially normalized during image scanning to adjust the average ratio between the two channels, using control spots. Spot intensities from scanned slides were quantified, using the Array-Pro 4.0 software (Media Cybernetics, Inc., Silver Spring, MD, USA). With this program, local corner background correction was carried out. Array-Pro 4.0 output data files (in Excel) were used to perform the lowest intensity normalization, standard deviation regularization, low intensity filtering, and dye-swap analysis, using the MIDAS computer program [68]. Normalization between different slides was carried out by centring [69]. MIDAS [68] was also used for replicate analysis and dye-swap filtering.

Bootstrap analyses with SAM enabled us to identify the differentially expressed genes, using a cut-off of two and adjusting the delta-delta $\mathrm{Ct}$ value, FDR, and FSN to minimize the number of false positives genes [70]. We conducted $k$-means clustering analysis to group the cDNA clones according to the similarity of their expression patterns, using $\mathrm{MeV}$ software available from TIGR and the default options [68].

\section{Sequence data analysis}

The 710 genes identified as differentially expressed were one-end sequenced. Sequence data were processed, using a PerlScript pipeline, to remove vector and low-quality sequences and to assemble sequences into a non-redundant set of sequences [71]. The Xoo MAI1 non-redundant set of sequences was deposited at GenBank's GSS Database http://www.ncbi.nlm.nih.gov/dbGSS/[72], under accession numbers FI978231- FI978329.

Processed sequences were initially searched against the NCBI database with BLASTN and TBLASTX http:// blast.ncbi.nlm.nih.gov/Blast.cgi[73], setting BLAST parameters to search against the complete non-redundant database and the genomes of Xoo strains KACC10331, MAFF311018, and PXO99A, and Xoc strain BLS256. A BLAST search was also performed with the partial genome of the African Xoo strain BAI3, which is currently being sequenced (Genoscope project 154/AP 2006-2007 and our laboratory, 2009, unpublished data). Results of these comparisons are summarized in the Additional file 1, Table S1. The Xoo MAI1 non-redundant set of sequences was grouped into functional categories, 
using Gene Ontology (GO), a functional classification scheme http://www.geneontology.org[74].

To establish if differentially expressed genes are located in the vicinity of the IS elements in the genomes of Xoo African strain BAI3 and Xoo Asian strain MAFF311018, we selected a region of $20 \mathrm{~kb}$ that flanked the IS elements in both the MAI1 and BAI3 genomes. BLAST searches were performed against these flanking sequences, using the Xoo MAI1 non-redundant set of sequences. For the sequences located within the $20-\mathrm{kb}$ sequence flanking the IS elements, the relative distance of each sequence to the IS element was calculated and compared between the two genomes.

\section{Southern blot analysis of differentially expressed genes}

Southern blot analysis was used to confirm that the DNA fragments derived from individual clones were present in the initial tester (Xoo MAI1 strain) and absent in the driver DNA (Xoo PXO86 or Xoc BLS256 strain). Eight genes (FI978063, FI978069, FI978079, FI978093, FI978109, FI978168, FI978197 and FI978322) were selected according to sequence similarities and library origin. Additionally, the gene FI978197 was selected to screen genomic DNA from different Xoo Asian strains (HN35, PXO339, PXO341, and PXO86), Xoo African strains (MAI1, BAI3, NAI8, and BAI4), Xoc African strains (MAI11 and MAI3), and the Xoc Asian strain BLS256 (Figure 2).

Briefly, for each strain, $5 \mu \mathrm{g}$ of genomic DNA was digested with 10 units of $R s a \mathrm{I}$ and run on $0.8 \%$ agarose gels. The DNA was transferred to Hybond- $\mathrm{N}^{+}$nylon membranes (Amersham Pharmacia Biotech) by capillary transfer. The insert DNA was amplified by PCR, using the nested primers provided with the PCR-Select ${ }^{\mathrm{m}}$ Bacterial Genome Subtraction Kit (Clontech Laboratories, Inc.). The amplified DNA fragment was gel purified, using the QIAquick Gel Extraction Kit (QIAGEN, Inc.), as recommended by the manufacturer. The DNA fragments were labelled with $\left[\alpha^{32} \mathrm{P}\right] \mathrm{dCTP}$ by random priming (MegaPrime labelling kit, Amersham Biosciences). Conditions of hybridization and washes were done at $65^{\circ} \mathrm{C}$. Filters were washed with three solutions: the first of $2 \times$ SSC and $0.1 \%$ SDS for $20 \mathrm{~min}$, followed by two washings with $1 \times$ SSC and $0.1 \%$ SDS for $10 \mathrm{~min}$ each, and a final wash with $0.1 \times$ SSC and $0.1 \%$ SDS for $20 \mathrm{~min}$. Blots were exposed on a PhosphorImager (model Storm 860, Amersham Pharmacia Biotech Inc.-Molecular Dynamics Division, Piscataway, NJ, USA).

\section{Validation by quantitative QRT-PCR}

We selected 14 genes that had been differentially expressed at various time points during infection by Xoo MAI1 for confirmation by QRT-PCR. The primers for quantitative detection were designed, using the Beacon
Designer $^{\mathrm{mm}}$ software (PREMIER Biosoft International, Palo Alto, CA, USA) (Table 4). All experiments were performed in triplicate. PCR mixtures were prepared, using FullVelocity ${ }^{\circ}$ SYBR ${ }^{\circ}$ Green QPCR Master Mix (Stratagene). PCR was performed on an Mx3005P thermal cycler (Stratagene), with the following cycling program: $95^{\circ} \mathrm{C}$ for $5 \mathrm{~min}$, followed by 40 cycles of $10 \mathrm{~s}$ at $95^{\circ} \mathrm{C}$ and $30 \mathrm{~s}$ at $60^{\circ} \mathrm{C}$.

Analysis was performed, using the delta-delta $\mathrm{Ct}$ method. The gene expression levels obtained by QRTPCR were normalized, using the $16 \mathrm{~S}$ ribosomal gene, which showed similar expression levels at different time points after infection. The gene expression level was compared between microarray and QRT-PCR. Similarly, the microarray ratio for each gene analysed was normalised against the microarray ratio obtained for $16 \mathrm{~S}$ ribosomal gene. This allowed direct comparison between the $16 \mathrm{~S}$ ribosomal gene-normalized QRT-PCR ratio and the $16 \mathrm{~S}$ ribosomal gene microarray ratio for each transcript investigated.

\section{Additional material}

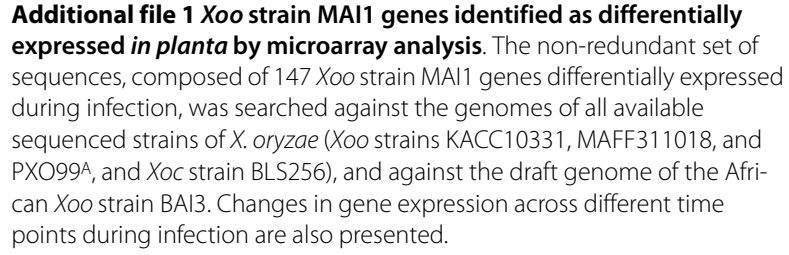

\section{Authors' contributions}

MS JT and VV designed the research project. MS DB and CG constructed the $\mathrm{SSH}$, prepared samples for microarray studies and performed the microarray experiments. MS and DB analyzed microarray data. MS and RG carried out sequence analysis, MS and BS designed QRT-PCR experiments. MS and W drafted the manuscript. All authors read and approved the final manuscript.

\section{Acknowledgements}

The authors thank J.Leach (CSU) and CM.Vera Cruz (IRRI) for providing us with DNA of Xoo strains. We thank B.Piégu for his help with sequence analyses. We thank Thierry Mathieu for his help during greenhouse experiments. We are very grateful to Michèle Laudié for her help in preparing the materials for sequencing and Richard Cooke for access to the Montpellier Languedoc-Roussillon Génopole sequencing facilities. The authors thank Ralf Koebnik for his critical reading on the first draft of the manuscript and his helpful suggestions. We thank anonymous reviewers for their valuable suggestions to improve the manuscript. We thank Elizabeth McAdam for editing. MS was supported by a doctoral fellowship awarded by Programme Alßan of the European Commission (grant E05D057941CO).

\section{Author Details}

1 UMR 5096 IRD-CNRS-Université de Perpignan, Laboratoire Génome et Développement des Plantes, Institut de Recherche pour le Développement, 911 Avenue Agropolis BP 64501, 34394 Montpellier Cedex 5, France,

2Biotechnology Research Unit, Centro Internacional de Agricultura Tropical (CIAT), A.A. 6713, Cali, Colombia and 'Laboratorio de Microbiología Molecular Centro de Biotecnología y Bioindustria, Corporación Colombiana de Investigación Agropecuaria (Corpoica), Km 14 via a Mosquera, Cundinamarca, Colombia 
Received: 28 September 2009 Accepted: 11 June 2010

Published: 11 June 2010

\section{References}

1. Nino-Liu D, Ronald P, Bogdanove A: Xanthomonas oryzae pathovars: model pathogens of a model crop. Mol Plant Pathol 2006, 7:303-324

2. Séré Y, Onasanya A, Verdier V, Akator K, Ouédraogo L, Segda Z, Coulibaly M, Sido A, Basso A: Rice Bacterial Leaf Blight in West Africa: Preliminary Studies on Disease in Farmers' Fields and Screening Released Varieties for Resistance to the Bacteria. Asian Journal of Plant Sciences 2005, 4:577-579.

3. Leach J, Rhoads M, Vera Cruz C, White F, Mew T, Leung H: Assessment of genetic diversity and population structure of Xanthomonas oryzae pv. oryzae with a repetitive DNA element. Appl Environ Microbiol 1992, 58:2188-2195

4. Nelson R, Baraoidan M, Vera Cruz C, Yap I, Leach J, Mew T, Leung H: Relationship between phylogeny and pathotype for the bacterial blight pathogen of rice. Appl Environ Microbiol 1994, 60:3275-3283.

5. Adhikari T, Mew T, Leach J: Genotypic and pathotypic diversity in Xanthomonas oryzae pv. oryzae in Nepal. Phytopathology 1999, 89:687-694

6. Vera Cruz CM, Bai J, Oña I, Leung H, Nelson RJ, Mew T-W, Leach JE: Predicting durability of a disease resistance gene based on an assessment of the fitness loss and epidemiological consequences of avirulence gene mutation. Proc Natl Acad Sci USA 2000, 97:13500-13505.

7. Koide T, Vencio R, Gomes S: Global gene expression analysis of the heat shock response in the phytopathogen Xylella fastidiosa. Journal of bacteriology 2006, 188:5821-5830.

8. Bronstein P, Filiatrault M, Myers C, Rutzke M, Schneider D, Cartinhour S: Global transcriptional responses of Pseudomonas syringae DC3000 to changes in iron bioavailability in vitro. BMC Microbiology 2008, 8:209.

9. Serrania J, Vorhölter F-J, Niehaus K, Pühler A, Becker A: Identification of Xanthomonas campestris pv. campestris galactose utilization genes from transcriptome data. Journal of Biotechnology 2008, 135:309-317.

10. Ferreira $A O$, Myers $C R$, Gordon JS, Martin GB, Vencato M, Collmer A, Wehling MD, Alfano JR, Moreno-Hagelsieb G, Lamboy WF, DeClerck G, Schneider DJ, Cartinhour SW: Whole-Genome Expression Profiling Defines the HrpL Regulon of Pseudomonas syringae pv. tomato DC 3000 , Allows de novo Reconstruction of the Hrp cisElement and Identifies Novel Coregulated Genes. Mol Plant Microbe Interact 2006, 19:1167-1179

11. Lan L, Deng X, Xiao Y, Zhou J-M, Tang X: Mutation of Lon Protease Differentially Affects the Expression of Pseudomonas syringae Type III Secretion System Genes in Rich and Minimal Media and Reduces Pathogenicity. Mol Plant Microbe Interact 2007, 20:682-696.

12. He Y, Xu M, Lin K, Ng Y, Wen C, Wang L, Liu Z, Zhang H, Dong Y, Dow J, Zhang $L$ : Genome scale analysis of diffusible signal factor regulon in Xanthomonas campestris pv. campestris: identification of novel cell-cell communication-dependent genes and functions. Molecular microbiology 2006, 59:610-622.

13. Shi XY, Dumenyo CK, Hernandez-Martinez R, Azad H, Cooksey DA: Characterization of Regulatory Pathways in Xylella fastidiosa: Genes and Phenotypes Controlled by gacA. Appl Environ Microbiol 2009, 75:2275-2283

14. He Y, Zhang L, Jiang B, Zhang Z, Xu R, Tang D, Qin J, Jiang W, Zhang X, Liao J, Cao J, Zhang S, Liang X, Wei M, Lu G, Feng J, Chen B, Cheng J, Tang J: Comparative and functional genomics reveals genetic diversity and determinants of host specificity among reference strains and a large collection of Chinese isolates of the phytopathogen Xanthomonas campestris pv. campestris. Genome Biol 2007, 8:R218.

15. Guidot A, Coupat B, Fall S, Prior P, Bertollaq F: Horizontal gene transfer between Ralstonia solanacearum strains detected by comparative genomic hybridization on microarrays. The ISME J 2009, 3:549-562

16. Seo Y-S, Sriariyanun M, Wang L, Pfeiff J, Phetsom J, Lin Y, Jung K-H, Chou $\mathrm{HH}$, Bogdanove A, Ronald P: A two-genome microarray for the rice pathogens Xanthomonas oryzae pv. oryzae and X. oryzae pv. oryzicola and its use in the discovery of a difference in their regulation of hrp genes. BMC Microbiology 2008, 8:99.

17. Tsuge S, Ayako F, Rie F, Takashi O, Kazunori T, Hirokazu O, Yasuhiro I, Hisatoshi K, Yasuyuki K: Expression of Xanthomonas oryzae pv. oryzae hrp Genes in XOM2, a Novel Synthetic Medium. J Gen Plant Path 2002, 68:363.

18. Lu S, Wang N, Wang J, Chen Z, Gross D: Oligonucleotide microarray analysis of the salA regulon controlling phytotoxin production by Pseudomonas syringae pv. syringae. Mol Plant Microbe Interact 2005, 18:324-333

19. Valls M, Genin S, Boucher C: Integrated regulation of the type III secretion system and other virulence determinants in Ralstonia solanacearum. PLoS pathogens 2006, 2:e82.

20. Wang N, Lu S, Wang J, Chen Z, Gross D: The expression of genes encoding lipodepsipeptide phytotoxins by Pseudomonas syringae pv. syringae is coordinated in response to plant signal molecules. Mol Plant Microbe Interact 2006, 19:257-269.

21. Lee BM, Park YJ, Park DS, Kang HW, Kim JG, Song ES, Park IC, Yoon UH, Hahn JH, Koo BS, Lee GB, Kim H, Park HS, Yoon KO, Kim JH, Jung CH, Koh $\mathrm{NH}$, Seo JS, GoS J: The genome sequence of Xanthomonas oryzae pathovar oryzae KACC10331 the bacterial blight pathogen of rice. Nucleic Acids Res 2005, 33:577-586.

22. Ochiai H, Inoue Y, Takeya M, Sasaki A, Kaku H: Genome sequence of Xanthomonas oryzae pv. oryzae suggests contribution of large numbers of effector genes and insertion sequences to its race diversity. Jpn Agri Res Quart 2005, 39:275-287.

23. Salzberg SL, Sommer DD, Schatz MC, Phillippy AM, Rabinowicz PD, Tsuge SA, Furutani A, Ochiai H, Delcher AL, Kelley D, Madupu R, Puiu D, Radune D, Shumway M, Trapnell C, Aparna G, Jha G, Pandey A, Patil PB, Ishihara H, Meyer DF, Szurek B, Verdier V, Koebnik R, Dow JM, Ryan RP, Hirata H, Tsuyumu S, Won Lee S, Seo YS, Sriariyanum M, Ronald PC, Sonti RV, Van Sluys MA, Leach JE, White FF, Bogdanove AJ: Genome sequence and rapid evolution of the rice pathogen Xanthomonas oryzae pv. oryzae PXO99A. BMC Genomics 2008, 9:204

24. Gonzalez C, Szurek B, Manceau C, Mathieu T, Sere Y, Verdier V: Molecular and pathotypic characterization of new Xanthomonas oryzae strains from West Africa. Mol Plant Microbe Interact 2007, 20:534-546.

25. Astua-Monge G, Freitas-Astua J, Bacocina G, Roncoletta J, Carvalho S, Machado M: Expression profiling of virulence and pathogenicity genes of Xanthomonas axonopodis pv. citri. Journal of bacteriology 2005, 187:1201-1205

26. Mehta A, Rosato Y: A simple method for in vivo expression studies of Xanthomonas axonopodis pv. citri. Curr Microbiol 2003, 47:400-403.

27. Thwaites R, Spanu PD, Panopoulos NJ, Stevens C, Mansfield JW: Transcriptional Regulation of Components of the Type III Secretion System and Effectors in Pseudomonas syringae pv. phaseolicola. Mol Plant Microbe Interact 2004, 17:1250-1258.

28. Soto-Suárez M, González C, Piégu B, Tohme J, Verdier V: Genomic comparison between Xanthomonas oryzae pv. oryzae and Xanthomonas oryzae pv. oryzicola, using suppression subtractive hybridization. FEMS Microbiol Lett 2010, 308:16-23.

29. Metha A, Rosato Y: Identification of differentially expressed genes of Xanthomonas axonopodis pv. citri by representational difference analysis. Genetics and Molecular Biology 2005, 28:140-149.

30. Tamir-Ariel D: Identification of genes in Xanthomonas campestris pv. vesicatoria induced during its interaction with tomato. J Bacterio/ 2007, 189:6359-6371.

31. Ashburner AM, Ball CA, Blake JA, Botstein D, Butler H, Cherry JM, Davis AP, Dolinski K, Dwight SS, Eppig JT, Harris MA, Hill DP, Issel-Tarver L, Kasarskis A, Suzanna L, Matese JC, Richardson JE, Ringwald M, Rubin GM, Sherlock G: Gene Ontology: tool for the unification of biology. Nature genetics 2000, 25:25-29.

32. Hilaire E, Young SA, Willard LH, McGee JD, Sweat T, Chittoor JM, Guikema JA, Leach JE: Vascular Defense Responses in Rice: Peroxidase Accumulation in Xylem Parenchyma Cells and Xylem Wall Thickening. Mol Plant Microbe Interact 2001, 14:1411-1419.

33. Han S-W, Park C-J, Lee S-W, Ronald P: An efficient method for visualization and growth of fluorescent Xanthomonas oryzae pv. oryzae in planta. BMC Microbiology 2008, 8:164

34. Clausen M, Koomey M, Maier B: Dynamics of Type IV Pili Is Controlled by Switching Between Multiple States. Biophysical Journal 2009, 96:1169-1177

35. Lim S-H, So B-H, Wang J-C, Song E-S, Park Y-J, Lee B-M, Kang H-W: Functional analysis of pilQ gene in Xanthomonas oryzae pv. oryzae, bacterial blight pathogen of rice. The Journal of Microbiology 2008, 46:214-220 
36. Mccarthy Y, Ryan R, O'dovan K, He Y, Jiang B, Feng J, Tang J, Dow J: The role of PilZ domain proteins in the virulence of Xanthomonas campestris pv. campestris. Molecular Plant Pathology 2008, 9:819-824.

37. Kang Y, Liu H, Genin S, Schell MA, Denny TP: Ralstonia solanacearum requires type 4 pili to adhere to multiple surfaces and for natural transformation and virulence. Molecular microbiology 2002, 46:427-437.

38. Liu H, Kang Y, Genin S, Schell MA, Denny TP: Twitching motility of Ralstonia solanacearum requires a type IV pilus system. Microbiology 2001, 147:3215-3229.

39. Meng Y, Li Y, Galvani C, Hao G, Turner J, Burr T, Hoch H: Upstream Migration of Xylella fastidiosa via Pilus-Driven Twitching Motility. J Bacteriol 2005, 187:5560-5567

40. Gottig N, Garavaglia BS, Garofalo CG, Orellano EG, Ottado J: A Filamentous Hemagglutinin-Like Protein of Xanthomonas axonopodis pv. citri, the Phytopathogen Responsible for Citrus Canker, Is Involved in Bacterial Virulence. PLOS ONE 2009, 4:e4358.

41. Guzzo CR, Salinas RK, Andrade MO, Farah CS: PILZ Protein Structure and Interactions with PILB and the FIMX EAL Domain: Implications for Control of Type IV Pilus Biogenesis. J Mol Biol 2009, 393:848-866.

42. Wang L, Makino S, Subedee A, Bogdanove AJ: Novel Candidate Virulence Factors in Rice Pathogen Xanthomonas oryzae pv. oryzicola as Revealed by Mutational Analysis. App/ Environ Microbiol 2007, 73:8023-8027.

43. Lerouge I, Vanderleyden J: O-antigen structural variation: mechanisms and possible roles in animal/plant-microbe interactions. FEMS Microbiol Rev 2002, 26:17-47.

44. Darsonval A, Darrasse A, Durand K, Bureau C, Cesbron S, Jacques M-A: Adhesion and Fitness in the Bean Phyllosphere and Transmission to Seed of Xanthomonas fuscans subsp. fuscans. Mol Plant Microbe Interact 2009, 22:747-757

45. de Souza AA TM, Coletta-Filho HD, Caldana C, Yanai GM, Muto NH, de Oliveira RC, Nunes LR, Machado MA: Gene expression profile of the plant pathogen Xylella fastidiosa during biofilm formation in vitro. FEMS Microbiol Lett 2004, 237:341-353.

46. Qi M, Nelson KE, Daugherty SC, Nelson WC, Hance IR, Morrison M, Forsberg CW: Novel Molecular Features of the Fibrolytic Intestinal Bacterium Fibrobacter intestinalis Not Shared with Fibrobacter succinogenes as Determined by Suppressive Subtractive Hybridization. J Bacteriol 2005, 187:3739-3751.

47. Rajeshwari R, Jha G, Sonti RV: Role of an In Planta-Expressed Xylanase of Xanthomonas oryzae pv. oryzae in Promoting Virulence on Rice. Mol Plant Microbe Interact 2005, 18:830-837.

48. White FF, Yang B: Host and Pathogen Factors Controlling the RiceXanthomonas oryzae Interaction. Plant Physiol 2009, 150:1677-1686.

49. Kay S, Bonas U: How Xanthomonas type III effectors manipulate the host plant. Current Opinion in Microbiology 2009, 12:37-43.

50. Yang B, Zhu W, Johnson LB, White FF: The virulence factor AvrXa7 of Xanthomonas oryzae pv. oryzae is a type III secretion pathwaydependent nuclear-localized double-stranded DNA-binding protein. Proc Natl Acad Sci USA 2000, 97:9807-9812.

51. Yang B, White F: Diverse members of the AvrBs3/PthA family of type III effectors are major virulence determinants in bacterial blight disease of rice. Mol Plant Microbe Interact 2004, 17:1192-1200.

52. Metz M, Dahlbeck D, Morales CQ, Al Sady B, Clark ET, Staskawicz BJ: The conserved Xanthomonas campestris pv. vesicatoria effector protein XopX is a virulence factor and suppresses host defense in Nicotiana benthamiana. The Plant Journal 2005, 41:801-814.

53. Jiang B-L, He Y-Q, Cen W-J, Wei H-Y, Jiang G-F, Jiang W, Hang X-H, Feng J$X$, Lu G-T, Tang D-J, Tang J-L: The type III secretion effector XopXccN of Xanthomonas campestris pv. campestris is required for full virulence. Research in Microbiology 2008, 159:216-220

54. Büttner D, Bonas U: Port of entry - the type III secretion translocon. Trends in Microbiology 2002, 10:186-192.

55. Sugio A, Yang B, White FF: Characterization of the hrpF Pathogenicity Peninsula of Xanthomonas oryzae pv. oryzae. Mol Plant Microbe Interact 2005, 18:546-554.

56. Lima W, Paquola A, Varani A, Van Sluys M, Menck C: Laterally transferred genomic islands in Xanthomonadales related to pathogenicity and primary metabolism. FEMS Microbiol Lett 2008, 281:87-97.

57. Zerillo M, Van Sluys M-A, Camargo L, Monteiro-Vitorello C: Characterization of new IS elements and studies of their dispersion in two subspecies of Leifsonia xyli. BMC Microbiology 2008, 8:127.
58. Monteiro-Vitorello C, de Oliveira M, Zerillo M, Varani A, Civerolo E, Van Sluys M: Xylella and Xanthomonas Mobil'omics. Omics 2005, 9:146-159.

59. Nierman WC, DeShazer D, Kim HS, Tettelin H, Nelson KE, Feldblyum T, Ulrich RL, Ronning CM, Brinkac LM, Daugherty SC, Davidsen TD, Deboy RT, Dimitrov G, Dodson RJ, Durkin AS, Gwinn ML, Haft DH, Khouri H, Kolonay JF, Madupu R, Mohammoud Y, Nelson WC, Radune D, Romero CM, Sarria S, Selengut J, Shamblin C, Sullivan SA, White O, Yu Y, Zafar N, Zhou L, Fraser CM: Structural flexibility in the Burkholderia mallei genome. Proc Natl Acad Sci USA 2004, 101:14246-14251.

60. Nagy Z, Chandler M: Regulation of transposition in bacteria. Res Microbiol 2004, 155:387-398

61. Mahillon J, Leonard C, Chandler M: IS elements as constituents of bacterial genomes. Res Microbiol 1999, 150:675-687.

62. Thieme F, Koebnik R, Bekel T, Berger C, Boch J, Buttner D, Caldana C, Gaigalat L, Goesmann A, Kay S: Insights into genome plasticity and pathogenicity of the plant pathogenic bacterium Xanthomonas campestris pv. vesicatoria revealed by the complete genome sequence. J Bacteriol 2005, 187:7254-7266.

63. Jeong E-L, Timmis JN: Novel Insertion Sequence Elements Associated with Genetic Heterogeneity and Phenotype Conversion in Ralstonia solanacearum. J Bacteriol 2000, 182:4673-4676.

64. Inoue $Y$, Takikawa Y: Investigation of Repeating Sequences in hrpL Neighboring Region of Pseudomonas syringae Strains. Ann Phytopathol Soc Japan 1999, 65:100-109.

65. Felipe López de F, Magni C, de Mendoza D, López P: Transcriptional activation of the citrate permease $P$ gene of Lactococcus lactis biovar diacetylactis by an insertion sequence-like element present in plasmid pCIT264. Mol Gen Genet 1996, 250:428-436.

66. Hasebe A, lida S: The Novel Insertion Sequences IS1417 IS1418 and IS1419 from Burkholderia glumae and Their Strain Distribution. Plasmid 2000, 44:44-53.

67. Kauffman H, Reddy A, Hsieh S, Merca S: An improved technique for evaluating resistance of rice varieties to Xanthomonas oryzae. Plant Dis Rep 1973, 57:537-541.

68. Saeed Al, Sharov V, White J, Li J, Liang W, Bhagabati N, Braisted J, Klapa M, Currier T, Thiagarajan M, Sturn A, Snuffin M, Rezantsev A, Popov D, Ryltsov A, Kostukovich E, Borisovsky I, Liu Z, Vinsavich A, Trush V, Quackenbush J: TM4: a free open-source system for microarray data management and analysis. Biotechniques 2003, 34:374-378.

69. Stekel D: Microarray Bioinformatics. Cambridge University Press Cambridge; 2003

70. Tusher VG, Tibshirani R, Chu G: Significance analysis of microarrays applied to the ionizing radiation response. Proc Natl Acad Sci USA 2001, 98:5116-5121.

71. Lopez C, Jorge V, Piégu B, Mba C, Cortes D, Restrepo S, Soto M, Laudie M, Berger C, Cooke R, Delseny M, Tohme J, Verdier V: A unigene catalogue of 5700 expressed genes in cassava. Plant Molecular Biology 2004, 56:541-554

72. Genome Survey Sequences Database [http://www.ncbi.nlm.nih.gov/ $\underline{\mathrm{dbGSS} /}$

73. BLAST (Basic Local Alignment Search Tool), BLAST Assembled Genomes [http://blast.ncbi.n/m.nih.gov/Blast.cgi]

74. The Gene Ontology [http://www.geneontology.org/]

doi: $10.1186 / 1471-2180-10-170$

Cite this article as: Soto-Suárez et al., In planta gene expression analysis of Xanthomonas oryzae pathovar oryzae, African strain MAI1 BMC Microbiology 2010, 10:170 